Section Editor

Mitchell S.V. Elkind, MD, MS

\title{
Teaching NeuroImages: \\ Central variant of posterior reversible encephalopathy syndrome
}

David Yen-Ting Chen, MD

Ying-Chi Tseng, MD

Hui-Ling Hsu, MD

Yen-Lin Huang, MD

Chi-Jen Chen, MD

Correspondence to

Dr. C.-J. Chen:

08889@shh.org.tw

Download teaching slides: Neurology.org
A 55-year-old man with chronic hypertension presented with acute headache and dizziness. Physical examination showed severe hypertension $(210 / 140 \mathrm{~mm} \mathrm{Hg})$ without any neurologic sign. Brain MRI showed diffuse brain edema over the brainstem, bilateral thalami, and cerebellar hemispheres with multiple microbleeds at bilateral basal ganglia (figure 1). His symptoms improved dramatically after antihypertensive therapy. Brain MRI 1 month later showed resolution of the edema (figure 2). "Central variant" of posterior reversible encephalopathy syndrome predominantly involving the brainstem and basal ganglia and relatively sparing the parieto-occipital lobe is rare. ${ }^{1}$ Paucity of brainstem signs and symptoms despite extensive neuroimaging abnormalities supports the diagnosis. ${ }^{2}$

\section{AUTHOR CONTRIBUTIONS}

Dr. David Chen studied the case, collected the information, and compiled the manuscript. Dr. Ying-Chi Tseng drafted and revised the manuscript for intellectual content. Dr. Yen-Lin Huang drafted and revised the manuscript for intellectual content. Dr. Yen-Lin Huang drafted and revised the manuscript for intellectual content. Dr. Chi-Jen Chen reviewed the manuscript.

\section{STUDY FUNDING}

No targeted funding reported.

\section{DISCLOSURE}

The authors report no disclosures relevant to the manuscript. Go to Neurology.org for full disclosures.

\section{REFERENCES}

1. McKinney A, Short J, Truwit C, et al. Posterior reversible encephalopathy syndrome: incidence of atypical region of involvement and imaging findings. Am J Radiol 2007;189:904-912.

2. Cruz-Flores S, Gondim F, Leira C. Brainstem involvement in hypertensive encephalopathy: clinical and radiological findings. Neurology 2004;62:1417-1419.
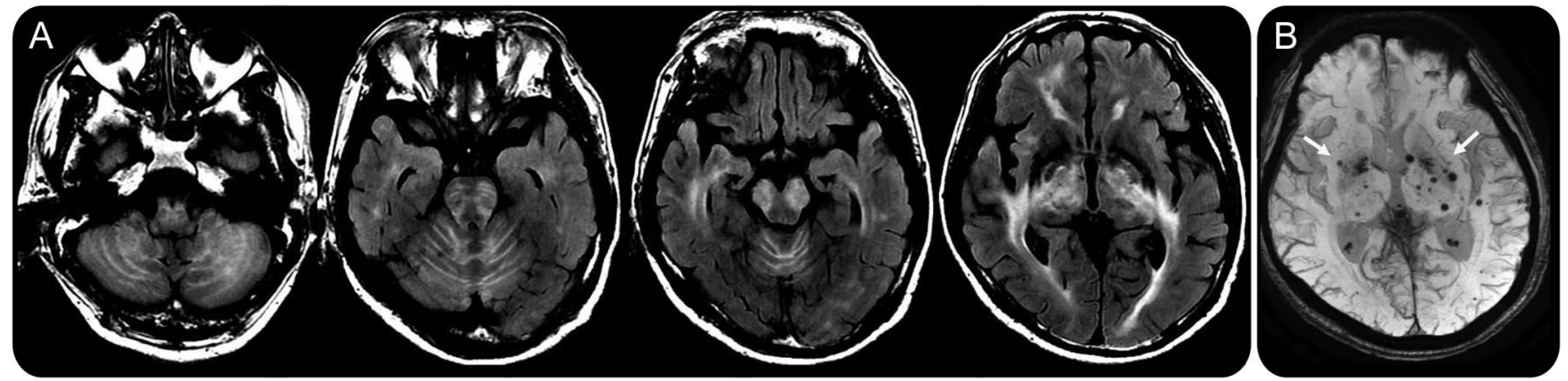

(A) T2-weighted axial images show diffuse hyperintensities over the brainstem, bilateral thalami, and cerebellar hemispheres. (B) Susceptibility-weighted images show multiple microbleeds at bilateral basal ganglia (arrows), suggestive of the underlying chronic hypertensive status.

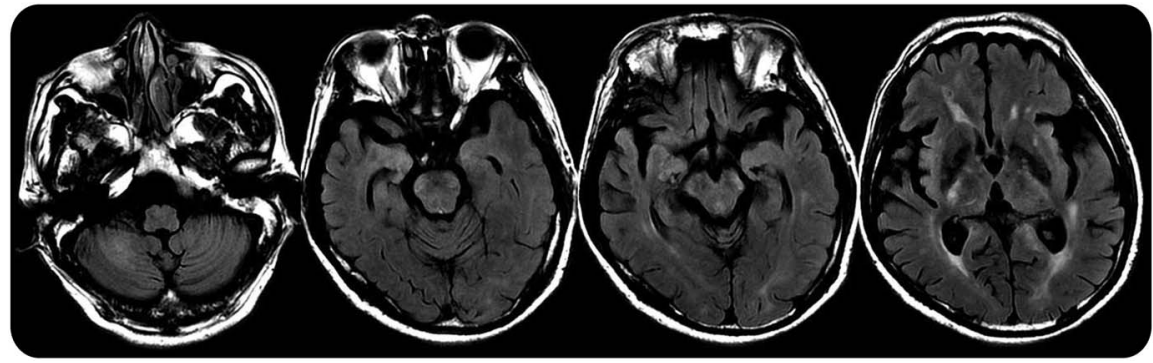

Brain MRI shows resolution of cerebral edema in the brainstem, cerebellum, and bilateral thalami.

From the Department of Medical Imaging, Taipei Medical University, Shuang-Ho Hospital, New Taipei City, Taiwan. 


\section{Neurology}

\section{Teaching NeuroImages: Central variant of posterior reversible encephalopathy syndrome \\ David Yen-Ting Chen, Ying-Chi Tseng, Hui-Ling Hsu, et al. \\ Neurology 2014;82; 164 \\ DOI 10.1212/WNL.0000000000000407}

\section{This information is current as of May 12, 2014}

Updated Information \&
Services
Supplementary Material
References
Subspecialty Collections
Permissions \& Licensing
Reprints

Updated Information \&

Supplementary Material

References

Subspecialty Collections

Reprints including high resolution figures, can be found at: http://n.neurology.org/content/82/19/e164.full

Supplementary material can be found at: http://n.neurology.org/content/suppl/2014/05/11/82.19.e164.DC1

This article cites 2 articles, 1 of which you can access for free at: http://n.neurology.org/content/82/19/e164.full\#ref-list-1

This article, along with others on similar topics, appears in the following collection(s):

\section{MRI}

http://n.neurology.org/cgi/collection/mri

Information about reproducing this article in parts (figures,tables) or in its entirety can be found online at:

http://www.neurology.org/about/about_the_journal\#permissions

Information about ordering reprints can be found online:

http://n.neurology.org/subscribers/advertise

Neurology ${ }^{\circledR}$ is the official journal of the American Academy of Neurology. Published continuously since 1951, it is now a weekly with 48 issues per year. Copyright () 2014 American Academy of Neurology. All rights reserved. Print ISSN: 0028-3878. Online ISSN: 1526-632X.

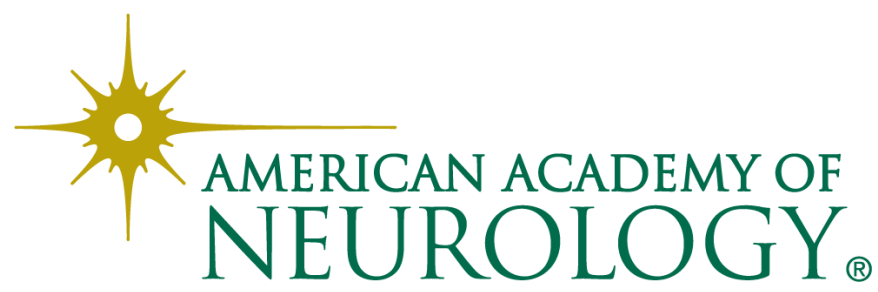

